Int. J. Morphol.,

33(1):73-76, 2015.

\title{
Aneurysm, Tortuosity and Kinking of Abdominal Aorta and Iliac Arteries in Thai Cadavers
}

\author{
Aneurisma, Tortousidad y Torsión de la Parte Abdominal de la \\ Aorta y de las Arterias Ilíacas en Cadáveres Tailandeses
}

Porntip Boonruangsri"; Bussakorn Suwannapong*; Somsiri Rattanasuwan* \& Sitthichai Iamsaard*

BOONRUANGSRI, P.; SUWANNAPONG, B.; RATTANASUWAN, S. \& IAMSAARD, S. Aneurysm, tortuosity, and kinking of abdominal aorta and iliac arteries in Thai cadavers. Int. J. Morphol., 33(1):73-76, 2015.

SUMMARY: The prevalence of the aneurysm, tortuosity, and kinking of abdominal aorta and iliac arteries is important for primary consideration in operative planning. The present study was undertaken to investigate the prevalence of abnormality of abdominal aorta and iliac arteries and demonstrate the patterns of kinking external iliac arteries in Thai cadavers. Eighty-five Thai embalmed cadavers (58 males and 27 females) were observed and measured the diameter of abdominal aorta and iliac arteries using a vernier caliper for assessment of aortic aneurysm (AAA). To investigate the tortuosity and kinking of iliac arteries, a standard goniometer was applied to measure the individual angle of iliac artery. In addition, the kinking patterns of external iliac artery were classified. The prevalence of AAA was $4.71 \%$ and the aneurysms of common and internal iliac arteries were 4.12 and $0.59 \%$. The tortuosity of common and external iliac arteries were 1.76 and $20 \%$. No tortuosity of internal iliac artery was observed. In addition, the kinking of common, external, and internal iliac arteries were 4.71, 16.47, and 1.18\%, respectively. Moreover, the patterns of external iliac aortic kinking were classified into 4 major types ( $\mathrm{S}$-shape; reversed $-\mathrm{C}$ shape; low grade shape; and $\mathrm{V}$-shape). We have observed the prevalence of the aneurysm, tortuosity, and kinking of abdominal aorta and iliac arteries in Thai cadavers. Currently, the 4 kinking variations of external iliac arteries were also first demonstrated.

KEY WORDS: Aneurysm; Tortuosity; Kinking; Abdominal aorta; Iliac arteries.

\section{INTRODUCTION}

In general, the dilation of the infrarenal abdominal aorta that exceeds 1.5 times or greater than $3 \mathrm{~cm}$ in diameter as compared to the normal aortic segment is called abdominal aortic aneurysm (AAA) (Prisant \& Mondy, 2004). Of iliac arterial aneurism, it has been reported that the diameter of the common iliac artery exceeds $2 \mathrm{~cm}$, while of external or internal iliac artery approximately exceeded $0.8 \mathrm{~cm}$ (Walker et al., 2010; Uberoi et al., 2011). In addition, the assessments of the tortuosity and kinking of arteries have also been described by magnetic resonance angiography (Del Corso et al., 1998; Schep et al., 2001; Kristmundson et al., 2012). The knowledge of prevalence, appropriate detection and surgical management of aortic aneurysm including the tortuosity and kinking of iliac arteries may be useful to decrease the rate of death from the ruptured aorta (Lederle et al., 1995). Some recognitions of these phenomenons are important for treating consideration in the optimizing radiation doses, endovascular stent grafting or traditional surgery (Marin et al., 1995; Quinn et al., 1997; Zarins et al., 1999; Derom \& Nout, 2005; Majewska et al., 2011). The objective of present study was to investigate the prevalence of the aortoiliac aneurysm including tortuosity and kinking of iliac arteries in Thai embalmed cadavers. In addition, we attempted to classify the kinking types of the external iliac artery observed.

\section{MATERIAL AND METHOD}

This study was carried out in 85 Thai embalmed cadavers ( 58 males and 27 females) with no vascular disease history, approximately aged between 29 to 95 years (averaged 67.19 \pm 15.11 years), during the period from June 2011 to May 2013, at the Department of Anatomy, Faculty of Medicine, Khon Kaen University. 
Assessment of aortic aneurysm. After opening the abdominopelvic wall, the internal organs underneath diaphragm were carefully removed from the posterior abdominal wall to observe and measure the diameter of abdominal aorta and iliac arteries using a vernier caliper. The measuments were performed three times on three different days. As described in a previous study, the abdominal aorta that exceeded $3 \mathrm{~cm}$ in diameter was considered as AAA (Prisant \& Mondy). In addition, the aneurism of common iliac artery was considered when its diameter exceeded $2 \mathrm{~cm}$, while of external or internal iliac artery was considered if its diameter exceeded $0.8 \mathrm{~cm}$ (Walker et al.; Uberoi et al.).
Assessment of the tortuosity and kinking of iliac arteries. Based on the idea of Schep et al., that detected the tortuosity and kinking of iliac artery by magnetic resonance angiography, this study was performed in cadavers by applying a standard goniometer to measure the individual angle of iliac artery. To consider the tortuosity, the angle of the artery was greater than 130 degrees whereas kinking angle was lesser than 130 degrees. Additionally, kinking variations of external iliac artery were classified.

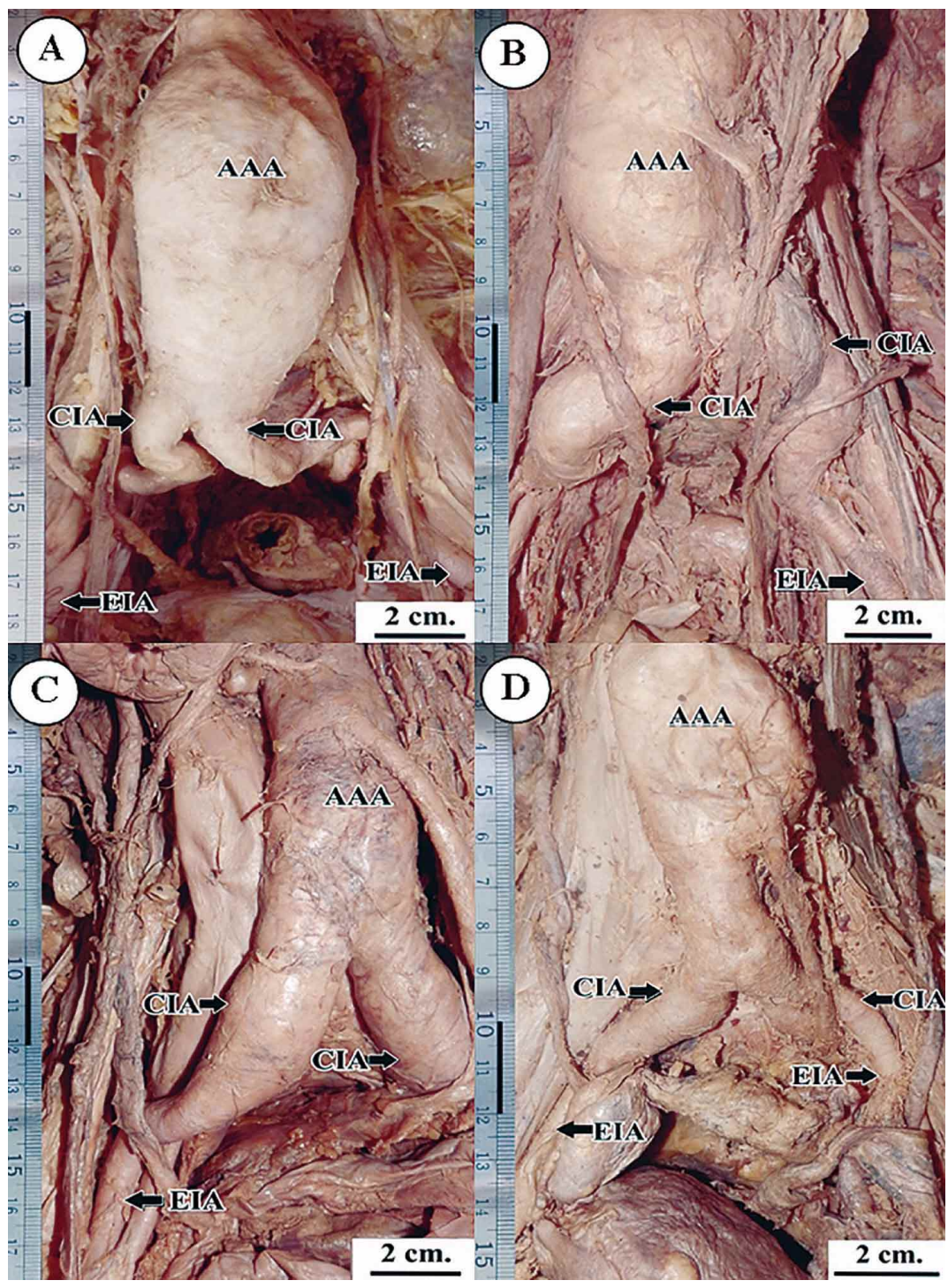

Fig. 1. Photographs showing the abdominal aortic aneurysm found in 4 of 85 Thai cadaveric specimens. The most width of aneurysm was measured; A) $5.74 \mathrm{~cm}, \mathrm{~B}) 4.02$ $\mathrm{cm}$, C) $3.67 \mathrm{~cm}$, and D) $3.27 \mathrm{~cm}$. AAA, abdominal aortic aneurysm; CIA, common iliac artery; EIA, external iliac artery; IIA, internal iliac artery.
In this study, AAA was found in 4 $(4.71 \%)$ cases (two males and two females) of in 85 specimens. The diameters of AAA were $5.74,4.02,3.67$, and $3.27 \mathrm{~cm}$ respectively (Fig. 1A-D). Additionally, the aneurysms of iliac arteries were observed (Table I). From 170 sides of common iliac arteries observed, the aneurysm was found in $7(4.12 \%)$ sides. Only internal but not external iliac artery was considered as aneurysm. It was found only on 1 side $(0.59 \%)$ of 170 sides (Table I). Its diameter was approximately $1.4 \mathrm{~cm}$.

Moreover, the tortuosity and kinking of iliac arteries were observed (Table I). In170 sides of common or external iliac artery, the tortousities were observed in $3(1.76 \%$, of common iliac artery) sides and in 34 (20\%, of external iliac artery). However, no tortuosity of internal iliac artery was found (Table I). In kinking assessments, these were found in common iliac artery (8 sides [4.71\%]), external iliac artery (28 sides [16.47\%]), and internal iliac artery (2 sides [1.18\%]), respectively (Table I).

Furthermore, the patterns of external iliac aortic kinking observed in this study (Fig. 2) were also recorded and could be classified into 4 major types (Sshape; reversed $-\mathrm{C}$ shape; low grade shape; and V-shape). Of 170 sides, there were found in the S-shape (14 sides [8.24 $\%]$ ), the reversed $-\mathrm{C}$ shape ( 2 sides [1.18 $\%]$ ), the low grade shape (9 sides [5.29 $\%]$ ) and the V-shape (3 sides [1.76\%]), respectively (Fig. 2). 
Table I. Showing prevalence of aortic aneurysm and tortuosity and kinking of iliac artery in 85 Thai cadavers.

\begin{tabular}{lccc}
\hline \multirow{2}{*}{ Arteries } & \multicolumn{3}{c}{ Sided number (\%) } \\
\cline { 2 - 4 } & Aneurysm & Tortuosity & Kinking \\
Abdominal aorta & $4(4.71 \%)$ & - & - \\
Common iliac artery & $7(4.12 \%)$ & $3(1.76 \%)$ & $8(4.71 \%)$ \\
External iliac artery & - & $34(20 \%)$ & $28(16.47 \%)$ \\
Internal iliac artery & $1(0.59 \%)$ & - & $2(1.18 \%)$ \\
\hline
\end{tabular}

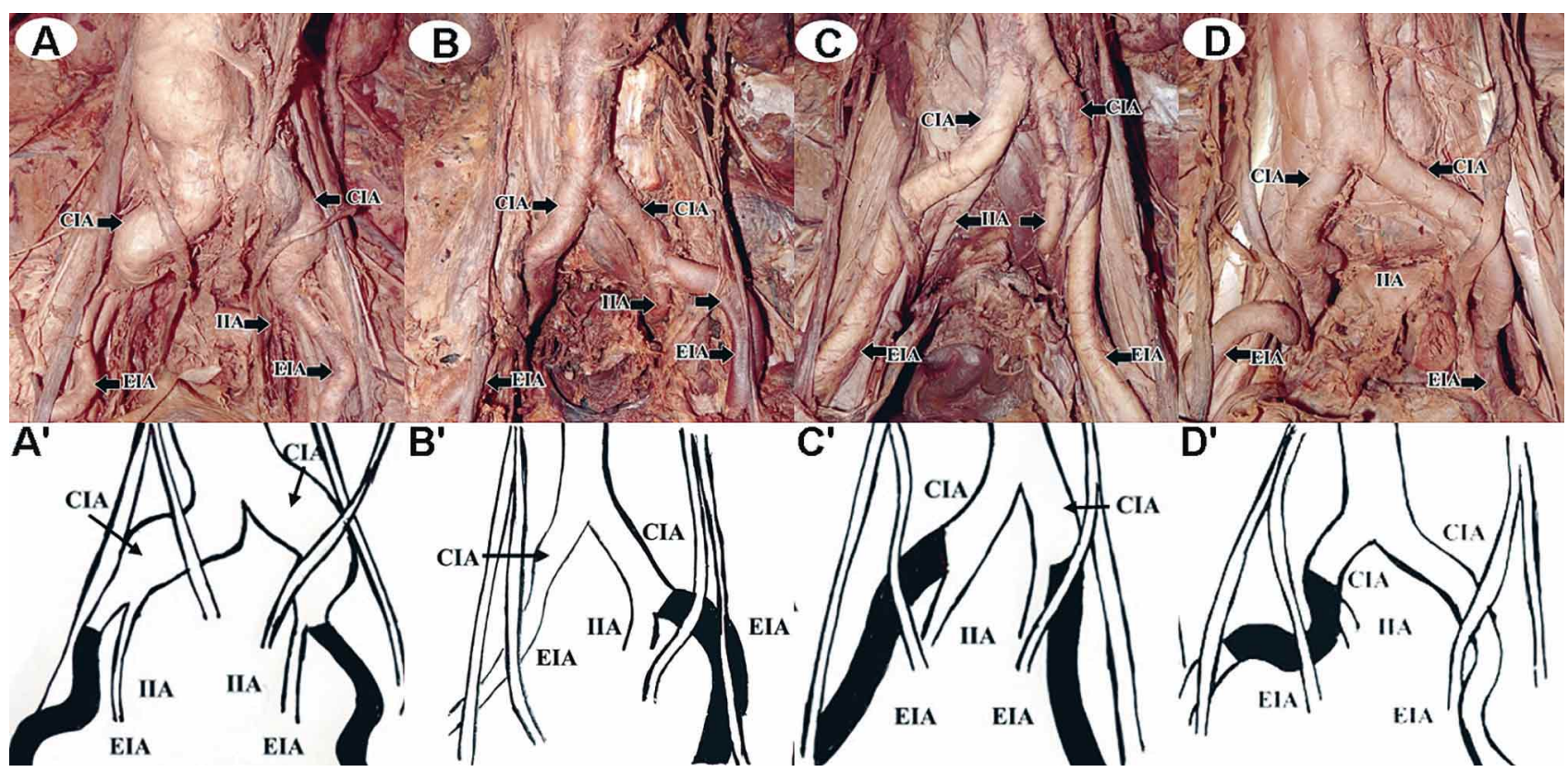

Fig. 2. Photographs (A-D) and schematics (A'-D') showing the 4 types of the external iliac aortic kinking observed in 85 Thai cadaveric specimens. A, A') S-shape; B, B') reversed -C shape; C, C') low grade shape; D, D'), V-shape. CIA, common iliac artery; EIA, external iliac artery; IIA, internal iliac artery.

\section{DISCUSSION}

Clinically, the detailed anatomic assessments of the aneurysm, tortuosity, and kinking of abdominal aorta and iliac arteries are required in consideration for endovascular aortic repair, such as endografting, at abdominopelvic region. For AAA, these anatomic features may include aortic neck length, diameter, and bifurcations (Sprouse et al., 2004). In particular, the data on three dimensions of aortoiliac tortuosity are very important for planning of endovascular repairs (Wolf et al., 2011; Kristmundson et al.). Together with computed tomography assessments, accumulatedanatomic data of abdomino-iliac artery features observed in cadaveric samples could be a primary source to determine as appropriate approach in endovascular repairs.

In this study, we found all abnormal types of abdomino-iliac arteries observed in Thai cadavers (Figs. 1 and 2, Table I). However, the aneurysm, tortuosity, and kinking of abdomino-iliac arteries (except external arteries) were less than 10 percent (Table I). It is possible that all cadavers investigated in this study had no history of vascular diseases (data not shown). Interestingly, only tortuosity (20\%), and kinking (16.4\%) of the external iliac artery was found to have high evidence as compared to those of other arteries (Table I). Assumed from this study, aging Thais may have a tendency of tortuosity and kinking of the external iliac artery. Moreover, we first demonstrated and classified the patterns of external iliac aortic kinking observed in Thai cadavers into 4 major types:S-shape, reversed, C shape, low grade shape, and V-shape, respectively (Fig. 2). Unfortunately, the computed tomography assessments of the aneurysm, tortuosity, and kinking of abdominal aorta and iliac arteries in Thai patients are limited to co-analyze with our results to elucidate particular prevalence. 
In conclusion, this study showed prevalence of the aneurysm, tortuosity, and kinking of abdominal aorta and iliac arteries and demonstrated 4 major kinking variations of external iliac arteries observed in Thai cadavers.
ACKNOWLEDGEMENTS. This study was supported by Department of Anatomy, Faculty of Medicine, Khon Kaen University. We also would like to thank the research cadaveric committee of the Department of Anatomy for their permission in this research.

BOONRUANGSRI, P.; SUWANNAPONG, B.; RATTANASUWAN, S. \& IAMSAARD, S. Aneurisma, tortousidad y torsión de las arterias aorta abdominal e ilíacas en cadáveres tailandeses. Int. J. Morphol., 33(1):73-76, 2015.

RESUMEN: La prevalencia de aneurisma, tortuosidad y torsión de la parte abdominal de la aorta y arterias ilíacas es relevante para la consideración primaria en la planificación quirúrgica. Se realizó un estudio para investigar la prevalencia de alteraciones en las parte abdominal de la aorta y arterias ilíacas y demostrar los patrones de torsión en las arterias ilíacas externas de cadáveres tailandeses. Se observaron 85 cadáveres tailandeses embalsamados ( 58 hombres y 27 mujeres); se midió el diámetro de la parte abdominal de la aorta y arterias ilíacas utilizando un pie de metro para la evaluación de aneurisma aórtico. Para investigar la tortuosidad y torsión de las arterias ilíacas, se utilizó un goniómetro estándar para medir el ángulo individual de la arteria ilíaca. Además, se clasificaron los patrones de torsión de las arterias ilíacas externas. La prevalencia de aneurisma aórtico fue 4,71\% y los aneurismas de las arterias ilíacas comunes e internas fueron 4,12\% y 0,59\%. La tortuosidad de las arterias ilíacas comunes y externas fueron $1,76 \%$ y $20 \%$. No se observó tortuosidad de la arteria ilíaca interna. Además, la torsión de las arterias ilíacas comunes, externas e internas fueron 4,71\%,16,47\% y 1,18\%, respectivamente. Por otra parte, los patrones de torsión fueron clasificados en 4 tipos principales (formas de S, de C invertida; de bajo grado y en V). Observamos la presencia de aneurisma, tortuosidad y torsión de la parte abdominal de la aorta y arterias ilíacas en cadáveres tailandeses. Demostramos también por primera vez, las 4 variaciones de torsión de las arterias ilíacas externas.

PALABRAS CLAVE: Aneurisma; Tortuosidad; Torsión; Aorta abdominal; Arterias ilíacas.

\section{REFERENCES}

Del Corso, L.; Moruzzo, D.; Conte, B.; Agelli, M.; Romanelli, A. M.; Pastine, F.; Protti, M.; Pentimone, F. \& Baggiani, G. Tortuosity, kinking, and coiling of the carotid artery: expression of atherosclerosis or aging? Angiology, 49(5):361-71, 1998.

Derom, A. \& Nout, E. Treatment of femoral pseudoaneurysms with endograft in high-risk patients. Eur. J. Vasc. Endovasc. Surg., 30(6):644-7, 2005.

Kristmundsson, T.; Sonesson, B. \& Resch, T. A novel method to estimate iliac tortuosity in evaluating EVAR access. J. Endovasc. Ther, 19(2):15764, 2012.

Lederle, F. A.; Wilson, S. E.; Johnson, G. R.; Reinke, D. B.; Littooy, F. N.; Acher, C. W.; Messina, L. M.; Ballard, D. J. \& Ansel, H. J. Variability in measurement of abdominal aortic aneurysms. Abdominal Aortic Aneurysm Detection and Management Veterans Administration Cooperative Study Group. J. Vasc. Surg., 21(6):945-52, 1995.

Majewska, N.; Juszkat, R.; B?aszak, M.; Frankiewicz, M.; Makalowski, M.; Stanisic', M.; Wachal, K. \& Majewski, W. Abdominal aorta aneurysm: Case report of high radiation dose during stent-graft implantation. Pol. J. Radiol., 76(4):60-2, 2011.

Marin, M. L.; Veith, F. J.; Lyon, R. T.; Cynamon, J. \& Sanchez, L. A. Transfemoral endovascular repair of iliac artery aneurysms. Am. J. Surg., 170(2):179-82, 1995.

Prisant, L. M. \& Mondy, J. S. 3rd. Abdominal aortic aneurysm. J. Clin. Hypertens. (Greenwich), 6(2):85-9, 2004

Quinn, S. F.; Sheley, R. C.; Semonsen, K. G.; Sanchez, R. B. \& Hallin, R. W. Endovascular stents covered with pre-expanded polytetrafluoroethylene for treatment of iliac artery aneurysms and fistulas. J. Vasc. Interv. Radiol., 8(6):1057-63, 1997.

Schep, G.; Kaandorp, D. W.; Bender, M. H.; Weerdenburg, H.; van Engeland, S. \& Wijn, P. F. Magnetic resonance angiography used to detect kinking in the iliac arteries in endurance athletes with claudication. Physiol. Meas., 22(3):475-87, 2001
Sprouse, L. R. 2nd; Meier, G. H. 3rd; Parent, F. N.; DeMasi, R. J.; Stokes, G. K.; LeSar, C. J.; Marcinczyk, M. J. \& Mendoza, B. Is three-dimensional computed tomography reconstruction justified before endovascular aortic aneurysm repair? J. Vasc. Surg., 40(3):443-7, 2004.

Uberoi, R.; Tsetis, D.; Shrivastava, V.; Morgan, R.; Belli, A. M. \& Subcommittee on Reporting Standards for Arterial Aneurysms of The Society for Vascular Surgery. Standard of practice for the interventional management of isolated iliac artery aneurysms. Cardiovasc. Intervent. Radiol.,34(1):3-13, 2011.

Walker, T. G.; Kalva, S. P.; Yeddula, K.; Wicky, S.; Kundu, S.; Drescher, P.; d'Othee, B. J.; Rose, S. C.; Cardella, J. F.; Society of Interventional Radiology Standards of Practice Committee; Interventional Radiological Society of Europe \& Canadian

Interventional Radiology Association. Clinical practice guidelines for endovascular abdominal aortic aneurysm repair: written by the Standards of Practice Committee for the Society of Interventional Radiology and endorsed by the Cardiovascular and Interventional Radiological Society of Europe and the Canadian Interventional Radiology Association. $J$. Vasc. Interv. Radiol., 21(11):1632-55, 2010.

Wolf, Y. G.; Tillich, M.; Lee, W. A.; Rubin, G. D.; Fogarty, T. J. \& Zarins, C. K. Impact of aortoiliac tortuosity on endovascular repair of abdominal aortic aneurysms: evaluation of 3D computer-based assessment. J. Vasc. Surg., 34(4):594-9, 2001.

Zarins, C. K.; White, R. A.; Schwarten, D.; Kinney, E.; Diethrich, E. B.; Hodgson, K. J. \& Fogarty, T. J. AneuRx stent graft versus open surgical repair of abdominal aortic aneurysms: multicenter prospective clinical trial. J. Vasc. Surg., 29(2):292-305, 1999.

Correspondence to:

Sitthichai lamsaard

Department of Anatomy - Faculty of Medicine

Khon Kaen University - 123 Mitraparp Road

Amphoe Muang

Khon Kaen, 40002

THAILAND

Received: 17-01-2014

Accepted: 21-02-2014

Email: sittia@kku.ac.th 